\title{
PENGALAMAN NARAPIDANA WANITA DALAM MENGHADAPI PRE MENSTRUAL SYNDROME (PMS) DI LEMBAGA PEMASYARAKATAN
}

\author{
Sri Hindriyastuti ${ }^{1}$, Anita Dyah Listyarini ${ }^{2}$ \\ ${ }^{1,2}$ STIKES Cendekia Utama Kudus \\ Email: hindriyas_tuti@yahoo.com
}

\begin{abstract}
ABSTRAK
Sebagai populasi minor dalam Lembaga Pemasyarakatan (lapas), wanita memiliki kebutuhan akan pelayanan kesehatan pada umumnya. Narapidana wanita juga mengalami siklus hamil, melahirkan menyusui dan menstruasi. Premenstrual syndrome (PMS) merupakan gejala tidak nyaman yang dirasakan oleh wanita usia reproduktif menjelang menstruasi atau beberapa hari di awal menstruasi. Ketika di Lembaga Pemasyarakatan, narapidana dengan banyak stressore yang memiliki riwayat pre menstrual syndrome ini tentu memiliki ragam pengalaman dalam berkompensasi dengan yang dialami sehingga penting untuk menggali lebih dalam pengalaman yang dialami dan dirasakan oleh para narapidana wanita dalam menghadapi PMS tersebut. Metode penelitian ini adalah deskriptif kualitatif dengan melakukan online in depth interview kepada empat Narapidana wanita. Tujuan penelitian ini untuk mengetahui pengalaman narapidana wanita dalam menghadapi Pre Mentrual Syndrom (PMS) selama di lembaga pemasyarakatan. Hasil penelitian ini menunjukkan bahwa dalam menghadapi PMS, para narapidana mengalami perasaan yang destruktif seperti cemas, tidak nyaman. Selain itu, narapidana membutuhkan support tenaga kesehatan di lembaga pemaysrakatan. Dalam kaitannya dengan penurunan intensitas nyeri PMS, narapidana merasa bahwa latihan aktifitas fisik yang diadakan oleh Lapas bisa membantu meringankan PMS yang dialami. Dengan demikian, pemberian dukungan secara fisik dan mental sangat diperlukan oleh narapidana menghadapi PMS selama masa tahanan mereka.
\end{abstract}

Kata Kunci: Narapidana Wanita, Lembaga Pemasyarakatan, Pre Mentrual Syndrom (PMS),

\section{ABSTRACT}

As a minor population in correctional institutions, women have a need for health services in general. Female prisoners experience cycles of pregnancy, childbirth, breastfeeding and menstruation. Premenstrual syndrome (PMS) is an uncomfortable symptom felt by women of reproductive age before menstruation or a few days at the start of menstruation. While in prisons, prisoners with premenstrual syndrome certainly have a variety of experiences in compensating for what they have experienced so it is important to dig deeper into the experiences experienced and felt by female prisoners in dealing with PMS. This research method is descriptive qualitative by conducting online in-depth interviews with four female prisoners. The purpose of this study was to determine the experience of female prisoners in dealing with Pre-Menstrual Syndrome (PMS) while in a correctional facility. The results of this study indicate that in dealing with PMS, prisoners experience destructive feelings such as anxiety, discomfort. In addition, prisoners need the support of health workers at the institute. In relation to the reduction in PMS pain intensity, prisoners feel that physical activity exercises organized by prisons can help relieve PMS experienced. Thus, providing physical and mental support is needed by prisoners facing PMS during their detention.

Keywords: Female Prisoners, Penitentiary, Pre Mentrual Syndrome (PMS), 


\section{LATAR BELAKANG}

Wanita merupakan populasi minor dalam Lapas namun mempunyai kebutuhan pelayanan kesehatan khusus karena kerentanan dan kelemahan mereka (Ramadhani, 2012). Selama fase pubertas wanita di Lapas juga memiliki aspek perkembangan reproduksi yang terkadang dibarengi oleh adanya ketidaknyamanan fisik selama beberapa hari awal menjelang periode mestruasi yang kerap kali dikenal dengan PMS. PMS atau Syndrom premenstruasi merupakan kumpulan gejala fisik, psikologis dan emosi yang terkait dengan siklus menstruasi wanita dengan gejala biasanya timbul 6-10 hari sebelum menstruasi dan menghilang ketika menstruasi dimulai. Mayoritas wanita pada usia reproduktif biasanya mengalami satu atau lebih gejala premenstruasi pada sebagian besar siklus menstruasi. Keparahan dan frekuensi gejala yang dialami bisa berbeda di antara masing masing siklus. Beberapa gejala psikologis yang umum dialami oleh para wanita diantaranya iritabilitas emosional dan tingkah laku, depresi, gelisah, kelelahan, kosentrasi berkurang. Gejala secara fisik yang umum dialami berupa pembengkakan dan rasa tidak nyaman pada payudara dan nyeri di daerah perut (Andansari, 2014).

Di Indonesia, angka kejadian sindrom premenstruasi / pre menstrual syndrome (PMS) berkisar 80 persen. Studi epidemiologi menunjukkan kurang lebih 20 persen dari wanita usia reproduksi mengalami gejala PMS dengan rentang sedang sampai berat. Sekitar 3-8 persen memiliki gejala hingga parah yang disebut dysphoric disorder (PMDD, sebagian kecil responden mengalami satu gejala dari sekian banyak gejala sindroma premenstruasi selama siklus menstruasi dalam 12 bulan terakhir (Fajrin, 2015).

Kondisi lapas yang banyak stressor seperti loss of family, loss of model dan lack of stimulation mempunyai efek langsung terhadap hormon esterogen progesteron dan berkurangnya kadar serotonin yang erat kaitannya dengan depresi, mudah tersinggung, kecemasan, gangguan tidur dan meningkatnya sensitifitas terhadap nyeri PMS (Dewi, Purwanta \& Hapsari, 2015). Di Lapas, kondisi narapidana wanita menghadapi PMS/PMDD ini belum mendapatkan perhatian khusus dalam sistem peradilan dan kesehatan. Isu gender yang menggambarkan realitas kehidupan wanita dan hal-hal yang berkaitan dengan kehidupan wanita dalam lapas juga masih jarang dilakukan penelitian. Narapidana wanita tentu saja membutuhkan pelayanan ginekologi dan obstetri, sayangnya belum ada data yang menunjukkan adanya perbedaan perlakuan pada wanita yang dalam siklus tersebut

American Nurses Association (ANA) menekankan pentingnya peran perawat dalam beberapa standar yang dibuat untuk memastikan pelayanan keperawatan yang diberikan kepada klien di area lapas (Sholehudin, 2003). Pengalaman menghadapi PMS bagi narapidana wanita akan sangat bervariasi. Fenomena ini tidak dapat digambarkan secara kuantitatif, karena pengalaman satu orang narapidana wanita dengan narapidana lain tentunya berbeda dalam menghadapi PMS, sehingga peneliti menggunakan pendekatan kualitatif. Hal ini menjadi dasar pentingnya menggali pengalaman narapidana wanita dalam menghadapi masa-masa PMS untuk mengetahui lebih lanjut sejauh mana narapidana wanita mendapatkan pelayanan kesehatan reproduksi, kebijakan-kebijakan, perencanaan dan program yang sesuai serta sejauh mana keterlibatan perawat correctional dalam situasi tersebut. Tujuan dari penelitian ini untuk mengetahui arti dan makna pengalaman menghadapi premenstrual syndrome pada wanita di lembaga pemasyarakatan.

\section{METODE PENELITIAN}

Penelitian ini menggunakan metode kualitatif dengan pendekatan fenomenologi, karena peneliti ingin memahami pengalaman subjektifitas yaitu pengalaman narapidana 
dalam menghadapi masa Pre Mentrual Syndrome (PMS) selama di Lapas. Informan dalam penelitian ini wanita di Lapas yang dalam satu tahun terahir mengalami PMS ketika mendapatkan menstruasi, dengan menggunakan teknik purposive sampling (nonprobability sampling). Jumlah informan dipilih oleh peneliti dalam penelitian ini tidak dibatasi, tetapi dihentikan oleh peneliti saat data saturasi tercapai (Braun \& Clarke, 2006). Pada penelitian ini, didapatkan sampel informan sejumlah empat orang Narapidana. Informan yang dipilih telah memenuhi kriteria inklusi antara lain: Berada di Lapas saat penelitian dilakukan, sehat secara jasmani dan rohani, perempuan usia produktif, tidak memiliki masalah kesehatan yang mengganggu proses wawancara, serta mengalami PMS (Pre menstrual Syndrom) minimal 3 kali dalam kurun waktu satu tahun terakhir. Proses penelitian dilakukan setelah menerima Informed Consent dari partisipant penelitian.

Penelitian ini dilakukan seacara online di Lapas Semarang, selama dua minggu yaitu pada tanggal 23 Juni 2020- 05 Juli 2020. Teknik pengumpulan data yang digunakan adalah wawancara mendalam (indepth interview) yang berjenis waawancara bebas terpimpin dan alat pengumpul data yang digunakan seperti format pedoman wawancara, buku tulis, pulpen serta alat penunjang yang mendukung lainnya seperti handphone sebagai alat perekam saat wawancara. Untuk mengelola data hasil wawancara peneliti menggunakan analisis tematik yang dilakukan oleh Braun dan Clarke (2006) yang terdiri dari 6 tahapan, yaitu: mengenali data, menginisialkan kode, mencari tema, meninjau tema, mendefinisikan tema dan nama tema, dan menghasilkan laporan.

\section{HASIL DAN PEMBAHASAN}

Partisipan yang telah ikut dalam penelitian ini berjumlah empat orang diantaranya partisipan satu dengan kode P1, inisial A, usia 27 tahun, alamat kecamatan Jepara, sudah menikah. Partisipan ke dua dengan kode P2, inisial B, usia 35 tahun, alamat Tegal, sudah menikah. Partisipan ke tigadengan kode P3 berusia 33 tahun, belum menikah, alamat Sragen. Partisipan ke empat, usia 23 tahun, dengan kode P4, belum menikah, alamat Semarang.

Berdasarkan hasil wawancara kepada empat narapidana wanita yang telah dilakukan oleh peneliti melalui telepon, partisipan menyatakan tidak mudah langsung menerima kondisi saat mengalami PMS, sehingga mengalami berbagai perasaan destruktif. Partisipan juga melakukan usaha mencari pengobatan di Lapas. Beberapa mengatakan perlunya adanya dukungan sosial dari tenaga kesehatan. Maka dari pernyataan tersebut, peneliti mengidentifikasikan uraian hasil wawancara tersebut dalam dua tema utama: perasaan destruktif dan perlunya dukungan tenaga kesehatan.

\section{Perasaan destruktif}

Berdasarkan hasil wawancara yang telah dilakukan, sebagian besar perasaan narapidana wanita saat mengalami PMS adalah tidak nyaman. Hal ini sesuai dengan pernyataan partisipan pertama dan kedua, yaitu sebagai berikut:

“..//..ya saya merasa tidak nyaman.. cemas mbak (P1)

“..//.tidak nyaman gitu lah..ndak enak..//.." (P2)

Partisipan ketiga menyatakan merasa khawatir dan tidak nyaman, ketika PMS, hal ini disampaikan sebagai berikut:

“../..nggak nyaman... saya kalau bisa ndak lah.. saya merasa ya gitu khawatir juga iya.. ndak nayman juga iya..//.. (P3)

Partisipan ke tiga dan ke empat menambahkan ia juga merasa takut. 
“..//..memang terus terang ya takut ..kalau mau haid ..//..” (P3)

Perasaan takut dan khawatir, stress, marah juga dialami oleh beberapa partisipan lainnya:

“...//.takut.. sih...iya.. tapi ya gitu sudah sering. "(P1)

“..//..ya memang bingung..//..seperti stres..//..” (P2)

“../...gimana ya (tampak berfikir) bawaannya pengin marah sih kadang...hahaha..(tertawa lepas).” (P3)

"../l..kadang sih rasanya stress lah.. yah kadang.. kadang juga marah-marah sendiri walaupun ndak seberapa (sambil manggut-manggut). ” (P4)

Kedua pernyataan tentang perasaan kaget dan sedih tersebut sesuai dengan penelitian yang dilakukan oleh Sholehudin (2003) yang menyatakan bahwa isu psikososial mewarnai kehidupan wanita di Lapas. Wanita memiliki kehangatan emosional, sikap kehati-hatian dan sensitifitas yang lebih tinggi daripada laki-laki dikarenakan wanita memiliki kondisi emosi didasarkan peran sosial yang diberikan oleh masyarakat dalam mengontrol peran agresif dan asertifnya (Sunggono, 2003). Proses PMS juga menimbulkan ketidakseimbangan hormon esterogen dan progesteron yang mana terjadi peningkatan hormon esterogen secara berlebih, sedangkan progesteron mengalami penurunan. Proses ini mempengaruhi tingkat psikologis emosional perempuan (Ramadhani, 2012). Sehingga, ada kecenderungan wanita merasa stress atau perasaan lain yang mengarah pada gangguan psikologis ringan.

\section{Aktifitas Lapas yang mendukung}

Para responden menyampaikan bahwa kegiatan Lapas terkadang bisa meringankan gejala PMS yang dialami. Hal ini disampaikan oleh sebagian besar partisipan sebagai berikut:

“../l.. kadang pas lagi ..hmm.. dapet gitu..pas sakit .. iku ikut olahraga..senam di sini ya..agak kurang.. iya kurang lah.”(P1)

“../l..olahraga sih..yah kadang senam gitu lah.. bisa sedikit ilang nyerinya.. tapi ya yang ringa-ringan aja lah" (P3)

“..//.. apa ya mbak.. ya itulah.. paling biar lupa sakitnya tak pakai kumpul temanteman, kadang ikut olargara ringan tapi."

Selain adanya aktifitas olahraga dari Lapas, kerjabakti di lapas juga mampu menurunkan tinkat gejala PMS. Hal ini disampaikan oleh semua prtisipan sebagai berikut.

“..//..bantu ..iya bantu pas ada kerja bakti ringan..ya ngobrol-ngobrol.. tiba-tiba ga begitu kerasa aja.” (P1)

“...//..apa ya.. kadang aktifitas ,ya ..kadang itu.. bantu bersih-bersih ..nyabutin rumput lah kadang .. ngobrol gitu sama teman-.. jadi lupa sakitnya.(P2)

“..//.. jarang sih.. Cuma ya kadang istirahat.. atau pas ndak sakit banget ..ngobrol sama teman.. buat ngilangin gitu.” (P3)

“../.. apa sih.. ngilangin ya? Oo ngurangin kan maksudnya.. bener.. kadang ikut pengajian di sini ya awalnya males karena sakit sih.. tapi lama-lama ilang kok. Aneh juga sih. Tapi ya gitu bisa aja.. hehe (tertawa). "(P4)

The American College of Obstetricians and Gynecologists (ACOG) menginfokan bahwa saat perempuan mendapat satu saja gejala fisik. dan satu gejala emosional, selama tiga kali masa menstraasi berturat-turut, hal itusudah dapat disebut menderita PMS, Gejala fisik yang kerap dirasakan saat PMS adalah kram, sakit perut, sakit kepala. mual, payudara bengkak, nyeri otot dan punggung, serta pembengkakan di tungkai tangan dan kaki. 
Sedangkan gejala psikologisnya, yaitu mudah marah, kesepian, tidak konsentrasi, malas,dan sulit tidur.

Menjelang menstruasi, kebiasaan olahraga dan aktifitas ringan lain bisa mengarah pada penurunan gejala PMS (Ramadhani, 2012). Minimnya aktifitas fisik, cenderung memperparah atau mendukung terjadinya PMS. Sehubungan dengan hal tersebut, para partisipan menyampaikan adanya penurunan tingkat nyeri dan ketidaknyamanan saat PMS melalui partisipasi aktifitas di Lapas, maka keterlibatan perempuan dalam aktifitas fisik atau kegiatan fisik lainnya dapat menurunkan gejala PMS. Beberapa sumber menyebutkan, latihan aerobik, atau senam ringan memang mampu secara efektif untuk mengurangi gejala yang muncul akibat PMS (Andansari, 2014; Pitajeng \& Nisman, 2016; Ramadhani, 2012). Hal ini disebabkan, dengan melakukan aktifitas fisik, akan terjadi peningkatan hormon endorphin, dan penurunan hormon estrogen dan steorid. Selain itu, juga mampu meningkatkan transportasi oksigen di dalam otot. Terlebih lagi, akan terjadi penekanan kadar kortisol dan peningkatan keadaan psikologis. Semua proses tersebut memberikan kesimpulan bahwa semakin teratur aktifitas fisik secara ringan dilakukan, semakin menurun tingkat gejala PMS. Secara psikologis, tampak bahwa mood, percaya diri, akan terbangun dengan adanya kegiatan atau aktifitas-aktifitas secara fisik.

Secara kimiawi, kadar serotonin yang yang tidak menentu selama siklus menstruasi memang berpengaruh terhadap kadar mood perempuan. Hal ini terjadi karena kadar serotonin memiliki hubungan denngan gejala depresi, kecemasan, kelelahan, agresif dan stress (Ramadhani, 2012).. Pada perempuan dengan PMS, kadar serotonin ditemukan rendah, akibatnya, perasaan perempuan di saat seperti ini cenderung mengalami variasi perasaan tersebut

\section{Perlunya Dukungan Tenaga Kesehatan}

Para responden penelitian menyampaikan bahwa di Lapas masih kurang dalam memberikan dukungan saat mereka mengalami PMS. Hal ini disampaikan oleh narapidana

“../..Ah.. apa mbak.. ya kadang memang ada yang ke sini, dokter, rutin sih, tapi ya gitu..diminta istirahat aja..//..”(P1).

"..//.. gimana ya (tampak berfikir).. ya gitu deh.. masih biasa aja, kami penginnya ya diperhatikan kalau mengeluhkan ..pas rasa sakit itu..//”(P2).

“..//..biasa aja .. perlu ada yang merhatikan khusus ..apalagi saat perlu obat..//.."(P3).

Para narapidana menginginkan support dukungan yang lebih saat mengeluhkan PMS.

“..//.. perlu lebih care ke kami lah saat begitu..//..” (P2)

“..//.. ya kami merasa sendiiri kadang..sih..hehehe (tertawa lirih)..//..” (P3)

Wanita memiliki kehangatan emosionalitas, sikap kehati-hatian dan sensitifitas yang kebih tinggi daripada laki-laki sehingga laki-laki memiliki lebih tinggi stabilitas emosional daripada wanita. Kondisi-kondisi tersebut menjadikan wanita menjadi salah satu populasi beresiko untuk mengalami masalah kesehatan, khususnya kesehatan jiwa. Masalah kesehatan di Lapas seperti PMS juga menjadi dasar pentingnya dukungan dan konseling kesehatan jiwa kepada wanita narapidana (Waluyo, 2000). Pemberian caring kepada narapidana menjadi bentuk dukungan yang dibutuhkan di saat mereka mengalami PMS tersebut.

Kebutuhan akan adanya support sistem /(dukungan) secara mental tersebut menjadi sinyal adanya keterbutuhan terhadap sistem caring perawat atau tenaga kesehatan dalam 
proses kepekaan terhadap PMS di dalam tahanan. Konsep caring sendiri, merupakan sentral dari praktik keperawatan jiwa dan komunitas dimana terdapat suatu garansi kualitas yang mampu meningkatan kesehaan dan kesembuhan serta merupakan komponen yang bisa diimplementasikan dalam kehidupan sehari-hari (Fatimah, Prabandari, \& Emilia, 2018). Dalam hal ini, menjadi sebuah konsep yang perlu ditekankan dalam Lapas di saat lingkungan narapidana dalam situasi tersebut. Dalam hal ini, perawat maupun tenaga kesehatan lain perlu kiranya memberikan pelayanan kesehatan secara menyeluruh (holistic) tidak hanya dari segi fisik saja tetapi juga dari segu dukungan psikologis/ mental.

Pendekatan holistik merupakan pendekatan yang sering digunakan oleh perawat untuk menyelesaikan masalah kesehatan klien secara menyeluruh. Pendekatan holistik dapat difasilitasi oleh peran perawat sebagai case manager. Dalam hal ini, perawat berperan serta dalam mengkaji dan merencanakan pelayanan kesehatan, penggunaan fasilitas pelayanan, mengkoordinasikan pelayanan interdisiplin, menghubungkan klien dengan sumber-sumber komunitas dan memonitor proses pelayanan.

\section{SIMPULAN DAN SARAN Simpulan}

Pre Menstrual Syndrome (PMS) merupakan kumpulan gejala fisik, psikologis, dan emosi yang berkaitan dengan siklus menstruasi wanita, dengan gejala yang muncul antara enam sampai 10 hari sebelum menstruasi dan menghilang ketika menstruasi dimulai. Perempuan usia produktif memiliki peluang terkena sindrom ini. Perempuan di Lapas dengan adanya beberapa masalah tekanan psikologis, dengan riwayat memiliki gejala PMS ini, memiliki pengalam yang beragam dalam proses menstruasinya. Sebagian besar partisipan menyampaikan adanya variasi perasaan destruktif seperti cemas, takut, stress, dan marah. Namun, semua partisipan setuju bahwa kegiatan fisik di Lapas seperti kerja bakti, pengajian maupun olahraga mampu meringankan gejala yang dialami oleh para partisipan. Hal yang paling penting adalah adanya keinginan yang sama dari partisipan untuk bisa mendapatkan dukungan dari pihak kesehatan di Lapas di saat mengalami PMS.

\section{Saran}

Tekanan selama di Lapas tentu bisa memperparah kondisi PMS tahanan, agar PMS dapat dikurangi, alangkah pentingnya bagi pihak Lapas untuk memberikan dukungan secara mental baik melalui Focus Group Discusion (FGD) atau aktifitas lain yang bisa memberikan dukungan secara psikologis untuk narapidana wanita dengan PMS. Adapun aktifitas fisik seperti olahraga, kerjabakti, bisa terus dipertahankan.

\section{DAFTAR PUSTAKA}

Andansari PA. Pemenuhan Hak Memperoleh Pelayanan Kesehatan Bagi Narapidana Wanita yang Sedang Hamil (Studi di Lembaga Pemasyarakatan Wanita Klas Iia Malang). Kumpulan Jurnal Mahasiswa Fakultas Hukum. 2014 Jan 7;1(1).

Clarke, V. and Braun, V., 2013. Teaching thematic analysis: Overcoming challenges and developing strategies for effective learning. The psychologist, 26(2) 
Fajrin R, RUSDIANA E. Pelaksanaan Hak Narapidana Atas Pelayanan Kesehatan dan Makanan yang Layak Di Lembaga Pemasyarakatan Klas IIA Bojonegoro. JURNAL NOVUM. 2015;2(2).

Dewi TK, Purwanta P, Hapsari ED. Pengalaman ibu menghadapi remaja dengan gejala premenstrual dysphoric disorder. Berita Kedokteran Masyarakat.;34(2):72-9.

Fatimah A, Prabandari YS, Emilia O. Stres dan kejadian premenstrual syndrome padamahasiswi di asrama sekolah. Berita Kedokteran Masyarakat.;32(1):13-8.

Kroll A. 2010.Recreational physical activity and premenstrual syndrome in college-aged women. The Graduate School of the University of Massachusetts .

Moeljatno. 2000. Asas-asas Hukum Pidana. Jakarta: Rineka Cipta

Muladi. 1998. Teori-teori Dan Kebijakan Pidana. Bandung: P.T Alumni

PITAJENG MS, Nisman WA, Kep S. Prevalensi Premenstrual Syndrome Dan Premenstrual Dysphoric Disorder Pada Wanita Di Lapas Klas Iia Kota Yogyakarta (Doctoral dissertation, Universitas Gadjah Mada).

Stres pada narapidana di Lpw Malang. Skripsi, Fakultas Psikologi Universitas Negeri Malang, Malang.

Prodjohamidjojo, Martiman. 1997. Memahami Dasar-Dasar Hukum Pidana II. Jakarta:Pradnya Paramita. IKIP Semarang Press

Ramadhani, 2012. Premesntrual syndrome, Jurnal Kesehatan Masyarakat, 7(1): 21-25

Ramadani,M, Triana,V, Diana,F. Hubungan aktivitasfisik, asupan kalsium dan magnesium dengan sindrom pramenstruasi mahasiswi PSIKM FK UNAND Tahun 2011. FKM UniversitasAndalas. Padang.2011

Sholehuddin, M. 2003. Sistem Sanksi Dalam Hukum Pidana. Jakarta: Rajawali Pers

Sunggono, Bambang. 2003. Metodologi Penelitian Hukum. Jakarta: Raja Grafindo. Persada

Supranto, J. 2003. Metode Penelitian Hukum dan Statistik. Jakarta: Rineka Cipta

Waluyo, Bambang. 2000. Pidana dan Pemidanaan. Jakarta: Sinar Grafika

KUHP (Kitab Undang-Undang Hukum Pidana) Undang-Undang No. 12 Tahun 1995 Tentang Pemasyarakatan 